\title{
A Statistical Analysis of Tropical Upper-Tropospheric Trough Cells over the Western North Pacific during 2006-15
}

\author{
DIAN WEN AND YING LI \\ State Key Laboratory of Severe Weather, Chinese Academy of Meteorological Sciences, Beijing, China \\ DA-LIN ZHANG \\ State Key Laboratory of Severe Weather, Chinese Academy of Meteorological Sciences, Beijing, China, and \\ Department of Atmospheric and Oceanic Science, University of Maryland, College Park, College Park, Maryland

\section{LiN XUE AND NA WeI} \\ State Key Laboratory of Severe Weather, Chinese Academy of Meteorological Sciences, Beijing, China
}

(Manuscript received 8 January 2018, in final form 26 August 2018)

\begin{abstract}
A statistical analysis of tropical upper-tropospheric trough (TUTT) cells over the western North Pacific Ocean (WNP) during 2006 to 2015 is performed using the NCEP Final reanalysis. A total of 369 TUTT-cell events or 6836 TUTT cells are identified, with a peak frequency in July. Most TUTT cells form to the east of $150^{\circ} \mathrm{E}$ and then move southwestward with a mean speed of $6.6 \mathrm{~m} \mathrm{~s}^{-1}$ and a mean life span of 4.4 days. About $75 \%$ of the TUTT cells have radii of $<500 \mathrm{~km}$ with 200 -hPa central heights of $<1239.4 \mathrm{dam}$. In general, TUTT cells exhibit negative height anomalies above $450 \mathrm{hPa}$, with their peak amplitudes at $200 \mathrm{hPa}$, pronounced cold anomalies in the 650-200-hPa layer, and significant cyclonic vorticity in the 550-125-hPa layer. A comparison of the composite TUTT cells among the eastern, central, and western WNP areas shows the generation of an intense cold-cored vortex as a result of the southward penetration of a midlatitude trough into a climatological TUTT over the eastern WNP region. The TUTT cell with pronounced rotation is cut off from the midlatitude westerlies after moving to the central WNP region, where it enters its mature phase, under the influence of northeasterly flow. The TUTT cell weakens in rotation and shrinks in size, diminishing within the TUTT after arriving at the western WNP region. Results suggest that, although most TUTT cells may diminish before reaching the western WNP, their vertical influences may extend to the surface layer and last longer than their signals at $200 \mathrm{hPa}$.
\end{abstract}

\section{Introduction}

An upper-level cold-core low is a cyclonic low pressure system in the upper troposphere that may produce important influences on the development of surface cyclones. Wang et al. (2012) classified upper-level cold-core lows into Palmén and Palmer types according to their locations and movements. The Palmén-type cold-core lows commonly come from cutoff lows of midlatitude troughs and thus mostly move eastward (Palmén and Nagler 1949), whereas the Palmer-type cold-core lows are those that develop near easterly troughs or saddle points south of a subtropical high and move westward under the prevailing easterly flow in the tropics (Palmer 1953).

Corresponding author address: Dr. Ying Li, yli@cma.gov.cn
The Palmén-type cold-core lows usually cause heavy rainfall and cold weather events (Hirota et al. 2016; Abatzoglou 2016), sometimes accounting for the generation of some extremely cold weather, for example, known as the northeast China cold vortex. Nieto et al. (2005) presented the first multidecadal climatology of cutoff low systems in the Northern Hemisphere and found the existence of three preferred areas of their occurrences: 1) extending from southern Europe to the eastern Atlantic coast, 2) in the eastern North Pacific, and 3) extending from the northern China-Siberian region to the northwestern Pacific coast. Most cutoff lows in the Northern Hemisphere last 2-3 days, with more frequent appearances in summer. In the Southern Hemisphere, cold-core lows are usually located near three main continental areas (i.e., Australia, South America, and 
Africa), with their maximum mean intensities during the austral winter (Campetella and Possia 2007; Singleton and Reason 2007; Pinheiro et al. 2017).

The Palmer-type cold-core lows are referred to as tropical upper-tropospheric trough (TUTT) cells by some researchers (e.g., Colton 1973; Ferreira and Schubert 1999), which are the major concern of the present study. A TUTT is an elongated, narrow, and cyclonic sheared zone (Whitfield and Lyons 1992), which occurs in the northern and southern Pacific and Atlantic Oceans during summer months, the so-called climatological TUTT (Sadler 1975; Ferreira and Schubert 1999). A TUTT is typically northeast-southwest oriented, stretching from the subtropics west of North America to the tropical North Pacific, with its west end located immediately to the east of a South Asian high (Wang and Wu 2016). A TUTT cell is a cold-core low pressure system forming within the TUTT that results from baroclinic wave development as a midlatitude trough penetrates into lower latitudes (Thorncroft et al. 1993). A TUTT cell could also form through barotropic instability of the lateral sheared flows associated with the TUTT (Colton 1973). The TUTT cell exhibits a closed cyclonic circulation in the upper troposphere, also known as a TUTT low or cutoff low. Sadler (1978) studied TUTT cells over the western North Pacific (WNP) and found that the cells, normally moving westward, are cold cored and are embedded in the troughs of convergent sinking air that is cloud free.

Kousky and Gan (1981) studied the development of upper-tropospheric cyclonic vortices in the tropical South Atlantic and indicated that the vortices, generally occurring near the axes of TUTTs, are characterized by cold cores with direct thermal circulations, that is, the cold air is sinking and the warm air on the periphery is rising. After examining a composite upper-tropospheric low from the 117 lows with rawinsonde observations at four WNP stations in four summers $(1967,1969,1970$, and 1971), Kelley and Mock (1982) found that the composite low is mostly confined in the layer of $700-100 \mathrm{hPa}$, with its maximum cyclonic circulation at $200 \mathrm{hPa}$, its maximum vertical motion and maximum cold anomaly both near $300 \mathrm{hPa}$, and its maximum warm anomaly at $125 \mathrm{hPa}$. Chen and Chou (1994) studied 60 cold lows during the warm months (i.e., June-October) of 1982-87 (1984 missing) over the western North Pacific, and noted that the frequency of their occurrences reaches a maximum in August and a minimum in October, with a mean moving speed of $4.1 \mathrm{~m} \mathrm{~s}^{-1}$ and a mean life span of 6.3 days. Using infrared satellite images and the National Centers for Environmental Prediction (NCEP)-National Center for Atmospheric Research (NCAR) reanalysis data, Chen et al. (2001) studied the spatial structures and basic dynamics of 25 North Pacific upper-tropospheric vortices over the six summers of 1993-98 and found that the vortices possess a well-organized cyclonic circulation in the middle-to-upper troposphere with a descending dry/ cold core encircled by moist ascending air around their peripheries.

TUTT cells could influence significantly the genesis, intensification, and tracks of tropical cyclones (TCs), depending on their relative positions between the two types of systems (Ferreira and Schubert 1999). For example, Gray (1968) showed that a TUTT cell may inhibit tropical cyclogenesis by increasing the vertical wind shear in which the TC is embedded. On the other hand, DeMaria et al. (1993) showed that the interaction of a TC with a TUTT cell can lead to the intensification of the storm. Cochran (1976) showed a brief history of a TUTT cell that developed into a surface low pressure system with tropical character. Sadler (1976) developed a conceptual model describing the role of TUTT cells in the early seasonal development of TCs. Fitzpatrick et al. (1995) showed the importance of TUTT cells in forecasting TC intensity, because of their associated intense vertical wind shear and horizontal eddy momentum fluxes. Patla et al. (2009) demonstrated that TUTT cells could play an important role in TC motion by influencing the TC's environmental steering flow. Li et al. (2012) found that a sharp northward turning of Typhoon Meranti (2010) is associated with a northwestwardmoving cold vortex on the northern side of the storm. Wei et al. (2016) indicated that a majority $(83 \%)$ of the upper-tropospheric cold lows over the WNP are associated with TUTTs and move westward in the tropical easterlies, while the rest are cutoff lows from midlatitude westerly troughs. Their analysis showed that the TUTT cells could influence the track and intensity of TCs when they are within a $15^{\circ}$ distance from TC centers.

It is evident that TUTT cells occur frequently over the WNP, and that they often play an important role in influencing the genesis and intensification as well as the movement of TCs. Although the previous studies have examined some spatial and temporal properties and three-dimensional structures of TUTT cells, their applicability is limited either because of a lack of highresolution data [e.g., upper-air observations at four rawinsonde stations used by Kelley and Mock (1982)] or because the analyses cover only a few summer months in 5-6yr using data prior to 2000 (e.g., Chen and Chou 1994; Chen et al. 2001). In particular, few statistical studies have been systematically performed to examine the climatology of TUTT cells up to date and the threedimensional structures of their associated mass and wind fields as well as their ambient environmental conditions during their different stages of development using the recent higher quality reanalysis data. Thus, the primary 

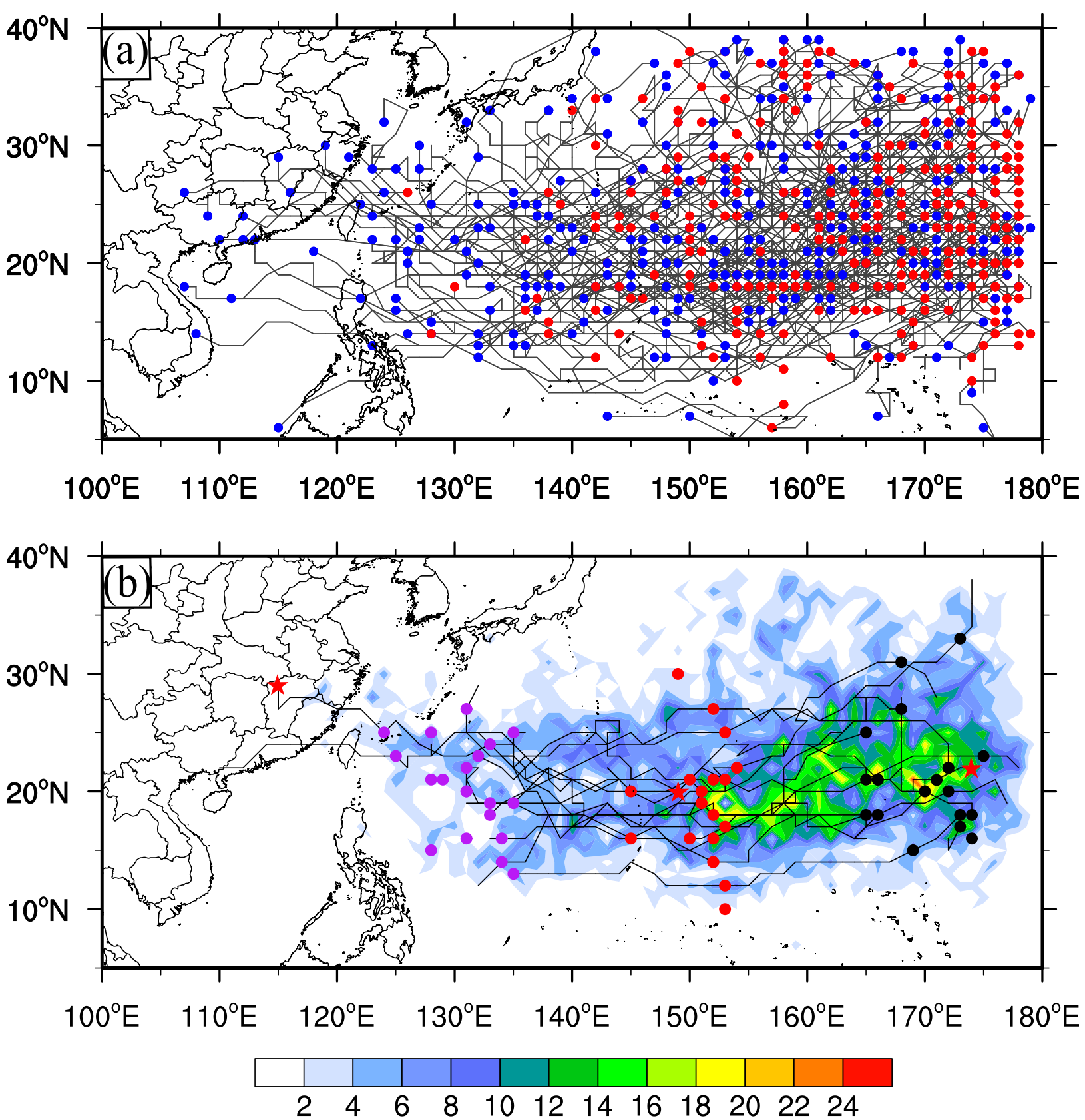

FIG. 1. (a) Tracks of TUTT cells over the WNP during 2006-15. Red and blue dots indicate the locations at which a TUTT-cell event is first identified or disappeared, respectively, with gray lines forming tracks between the red and blue dots. (b) Spatial distribution of TUTT cells at 6-hourly intervals during 2006-2015. Dots in purple, red, and black denote the 20 TUTT cells taken over the offshore, central, and eastern WNP, respectively, which are used to show their composite structures in Figs. 6-9, below (see text for more detail). A few of the dots overlap. Lines connecting the colored dots in (b) represent those (13) TUTT cells that moved from the eastern to western WNP regions, and red stars are used to show one long-lived TUTT cell mentioned in the text.

purpose of this study is to update and provide a more complete analysis of the climatological characteristics, structures, and larger-scale circulations of TUTT cells occurring in all months over the WNP using the 10-yr global reanalysis data of 2006-15. In addition, the origins of TUTT cells will be explored with the high-quality dataset, since there are still conflicting views on the mechanisms by which they are generated.

The next section describes the data and method used for this study. Section 3 is dedicated to the description of general climatological variations of TUTT cells in terms of their spatiotemporal characteristics, size, intensity, 
and life span. Section 4 presents the statistical vertical properties of the associated cold anomalies and vorticity as well as their vertical profiles in the core region. Section 5 shows the three-dimensional structures and larger-scale circulations of three composite TUTT cells that are taken over their formation, mature, and diminishing areas, respectively. A summary and concluding remarks are given in the final section.

\section{Data source and method}

To study the statistical characteristics of TUTT cells over the WNP, a region of $0^{\circ}-40^{\circ} \mathrm{N}, 100^{\circ} \mathrm{E}-180^{\circ}$ is selected, as given in Fig. 1, as based on some previous studies (e.g., Chen and Chou 1994; Chen et al. 2001; Wei et al. 2016). The associated meteorological variables during the 10-yr period of 2006-15 are derived from the NCEP Final (FNL) global reanalysis at $1.0^{\circ}$ grid resolution and 6-hourly intervals, with 21 levels below $100 \mathrm{hPa}$. A TUTT cell event is defined as a cyclonic vortex originating from a TUTT, namely, starting from the appearance of a closed geopotential height contour at 2-dam intervals at $200 \mathrm{hPa}$ and ending with the disappearance of the closed contour. A cold core is checked to exclude any warm-cored vortex such as a TC. Any cold-low event of less than $24 \mathrm{~h}$ is also excluded. The intensity of a TUTT cell may be expressed in terms of its minimum central height at $200 \mathrm{hPa}$, or its maximum cold anomaly and maximum relative vorticity. A TUTT-cell center is defined at the minimum depression within a closed geopotential height contour at $200 \mathrm{hPa}$, with its intensity expressed by the central minimum value of the closed contour. Its radial size is defined as the mean distance between the center and the maximum closed geopotential height contour in the east, west, south, and north directions.

A temperature anomaly of a TUTT cell is obtained by calculating the difference between the mean temperature in the central area (i.e., covering $3 \times 3$ grid points) and the mean temperature in its surrounding area (i.e., covering $41 \times 41$ grid points) at each level. Both covered areas are centered at the position of the TUTT cell's minimum height, and a minimum value in the layer of $500-100 \mathrm{hPa}$ is defined as the peak cold-cored temperature anomaly. Note that all the mean variables are obtained by area averaging each grid box, since its area coverage becomes smaller toward higher latitudes. The level in the 500-100-hPa layer, at which the cyclonic vorticity in the central area is peaked, is defined as the vorticity center of the TUTT cell. When more than one cell occurs at the same position, their mean values will be recorded. The above procedures are also used to obtain the vertical profiles of the temperature, specific humidity, and three-dimensional geopotential height deviations as well as the mean relative vorticity and vertical velocity of the TUTT cell.

Using the above method, a total of 369 TUTT-cell events, or 6836 TUTT cells when counted at 6-h intervals, over the WNP during the 10-yr period from 2006 to 2015 are identified. To distinguish the TUTT-cell events from the number of TUTT cells counted at 6-h intervals, the latter will be referred hereinafter to as the TUTT-cell frequency.

\section{General statistical characteristics}

In this section, we present the spatial and temporal characteristics of the TUTT-cell events and then examine the statistical properties of radial size, the central low's height (i.e., intensity) at $200 \mathrm{hPa}$, the movement of the TUTT cells, and the life span of the associated events.

\section{a. Spatial and temporal variations}

Figure 1a shows the tracks of all 369 of the TUTT-cell events that are identified during the period 2006-15. Most of them (i.e., 96.7\%) are initiated, as denoted by red dots, to the east of $150^{\circ} \mathrm{E}$, albeit with a few forming near the westernmost longitude of $125^{\circ} \mathrm{E}$. Unlike the general tracks of TCs, the ending or disappearing positions of TUTT cells, denoted by blue dots, are distributed from the eastern boundary of the study domain to the westernmost longitude of $107^{\circ} \mathrm{E}$. Despite the much less organized tracks, more ending positions are seen over the central portion of the distributed track region. Thus, most TUTT cells move generally westward or southwestward, which is in agreement with the work of Chen and Chou (1994) and Chen et al. (2001). A few of them could reach as far as the inland regions of mainland China. Some of the remaining TUTT cells move eastward, mainly as a result of the eastward movement of the TUTTs in which they are embedded, and the rest move north to northeastward, likely as a result of the south-tosouthwesterly steering flows associated with a subtropical high. It is worth mentioning that 13 TUTT cells moved from the eastern to the western portion of the WNP (Fig. 1b), accounting for $3.5 \%$ of the total TUTTcell events identified. For example, one of them (indicated by red stars in Fig. 1b) is initiated and dissipated at 0000 UTC 11 August and 1200 UTC 20 August 2010, respectively, traveling a distance of about $5900 \mathrm{~km}$ from $22^{\circ} \mathrm{N}, 174^{\circ} \mathrm{E}$ to $29^{\circ} \mathrm{N}, 115^{\circ} \mathrm{E}$.

The spatial distribution of the frequency of TUTT-cell occurrences is given in Fig. 1b, showing that the TUTT cells appear more frequently over an elongated opensea zone of $15^{\circ}-25^{\circ} \mathrm{N}$ and $150^{\circ}-175^{\circ} \mathrm{E}$. This elongated zone is typically the location of most TUTT bases where 
TUTT cells form, which is more or less in agreement with the study of Chen and Chou (1994). In section 5, some TUTT cells occurring over the eastern and central WNP and offshore regions, denoted by dots in purple, red, and black, respectively, in Fig. 1b, will be selected to examine their composite three-dimensional structures at the early formation and mature and weakening stages. Few TUTT cells appear to the south of $10^{\circ} \mathrm{N}$, indicating the importance of Earth's rotation in forming or maintaining the associated cyclonic vortices, just like the formation of TCs. In addition, few cells appear to the north of $30^{\circ} \mathrm{N}$ because of the presence of dominant westerly flows.

Figure 2 a shows the annual variations of TUTT-cell events and frequencies, both of which exhibit significant year-to-year fluctuations, but with a decreasing trend with time. The domain-averaged annual number of TUTT-cell events is 37, with a peak of 42 in 2008 and a nadir of 27 in 2014. The results are similar for the maximum and minimum annual frequencies of TUTT cells except for 2009 and 2014, the frequencies of which drop sharply. Of interest is that the latter two years coincide with the El Niño years of 2009/10 (Kim et al. 2011) and 2014/15 (Chiodi and Harrison 2017), respectively. During an El Niño year, higher sea surface temperatures over the eastern Pacific tend to increase oceanic convection (Wu 1992), leading to weaker continental-oceanic gradients in diabatic heating. According to Fitzpatrick et al. (1995), the formation of TUTTs is closely related to the continental-oceanic gradients of total diabatic heating, including sensible, latent, and radiative heating. Thus, we may speculate that the rapid drop in the frequency of TUTT cells in 2009 and 2015 could be attributed to the formation of fewer TUTTs in the occurrence of El Niño events.

The monthly variations of TUTT cells are given in Fig. 2b, showing that they can be observed from March to December, when the TUTT circulation over the WNP is pronounced (not shown), given the fact that the TUTT cells propagate southwestward within the TUTT. Their maximum and minimum frequencies appear in July and December, respectively. This result differs slightly from the respective maximum and minimum frequency in August and October found by Kelley and Mock (1982), who used four summers of data from four WNP sounding stations. About $91 \%$ of the TUTT-cell events occur during the months of May-October, which coincide with the active period of typhoon development.

\section{b. Size, height intensity, movement, and life span}

Figure 3 shows box-and-whisker plots of the radii, central minimum geopotential heights, moving speeds, as well as the life span of the TUTT-cell events. We see
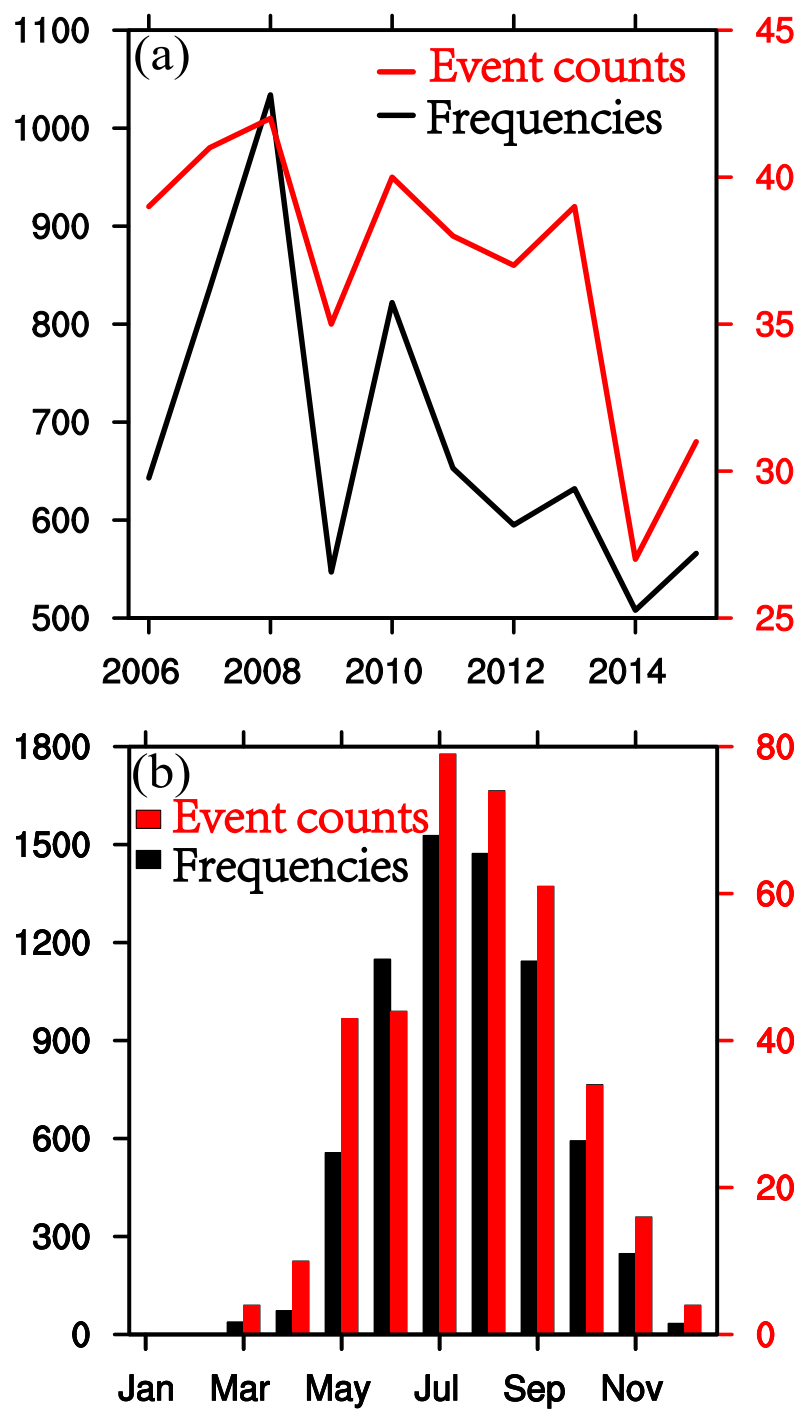

FIG. 2. Time series of (a) the annual frequencies (black; left $y$ axis) at 6-h intervals and the event counts (red; right $y$ axis) with full life spans of TUTT cells and (b) their corresponding monthly variations (black bars for frequencies; left $y$ axis) (red bars for event counts; right $y$ axis) during 2006-15.

that the mean, maximum, and minimum radii of the TUTT cells are $4^{\circ}, 10^{\circ}$, and $1^{\circ}$, respectively, with $75 \%$ of them having radii of less than $5^{\circ}$ (Fig. 3a). Although the mean size obtained herein is smaller than that of about $7^{\circ}$ found by Chen et al. (2001), it is still larger than that of a typical typhoon and smaller than that of a typical midlatitude cyclone. In general, the cell sizes are larger over the formation area to the east and much smaller than the mean size over the diminishing regions to the west. We also find a uniform distribution of cell sizes across the study domain, with little monthly variation (not shown). The 200-hPa mean, lowest, and highest geopotential heights at the TUTT cells' centers are 

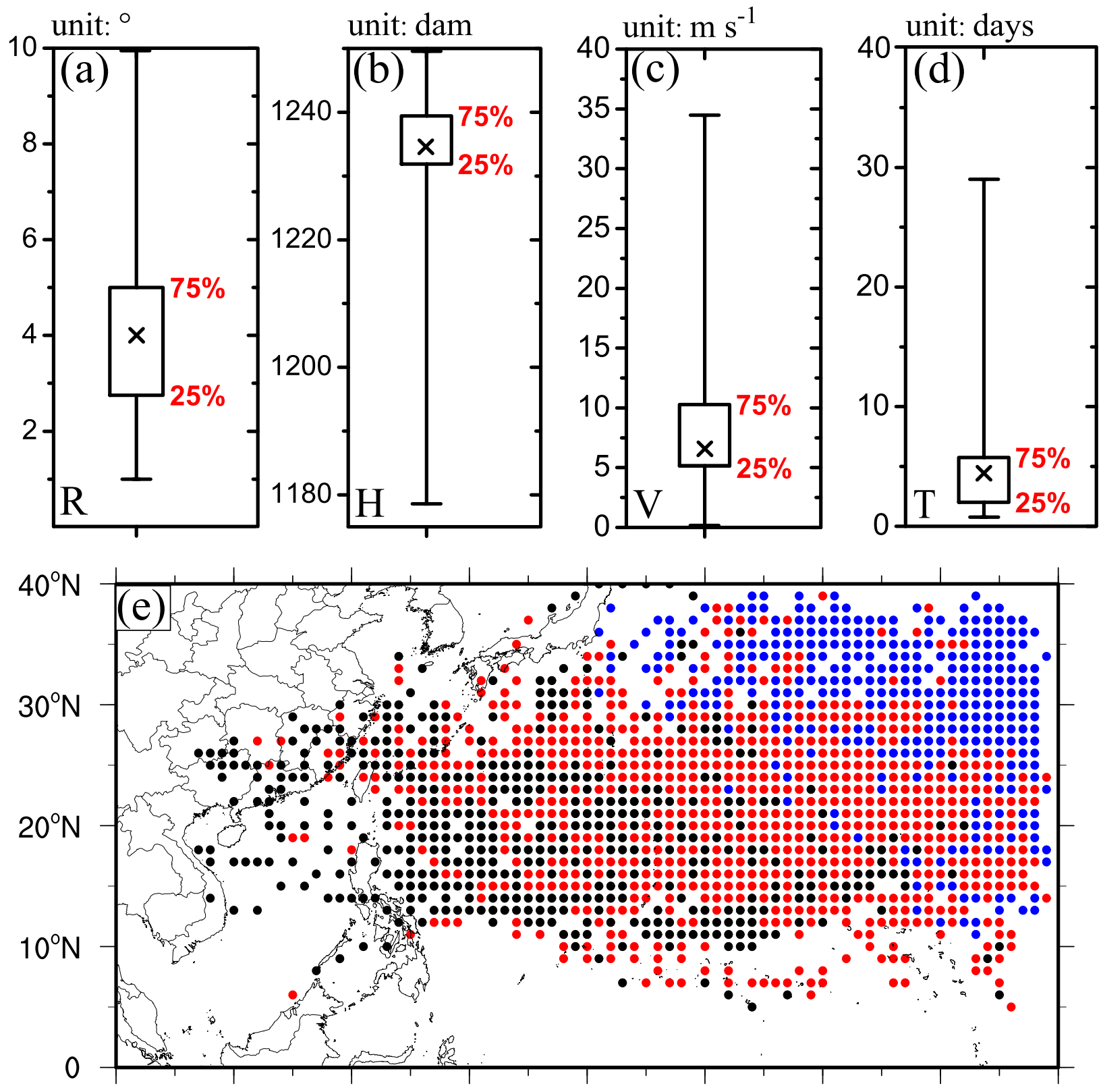

$100^{\circ} \mathrm{E} \quad 110^{\circ} \mathrm{E} \quad 120^{\circ} \mathrm{E} \quad 130^{\circ} \mathrm{E} \quad 140^{\circ} \mathrm{E} \quad 150^{\circ} \mathrm{E} \quad 160^{\circ} \mathrm{E} \quad 170^{\circ} \mathrm{E} \quad 180^{\circ} \mathrm{E}$

$$
\mathrm{H} \leqslant 1231 \bullet 1231<\mathrm{H} \leqslant 1239 \bullet \mathrm{H}>1239
$$

FIG. 3. Box-and-whisker plots of the (a) radius $R\left(^{\circ}\right)$, (b) minimum geopotential height at $200 \mathrm{hPa} H$ (dam), (c) moving speed $V\left(\mathrm{~m} \mathrm{~s}^{-1}\right.$ ), (d) life span $T$ (h), and (e) geographical distribution of the TUTT cells' centers at $200 \mathrm{hPa}$, as determined by the minimum geopotential height contours (dots in blue, red, and black denote $H \leq 1231,1231<H \leq 1239$, and $H>1239$ dam, respectively) of the total 6836 TUTT cells during the 10-yr period of 2006-15. The symbols in the boxes in (a)-(d) denote the mean value.

1234.6, 1178.6, and 1249.5 dam, respectively, with $75 \%$ of their intensities being less than 1239.4 dam (Fig. 3b). Figure $3 e$ shows that the TUTT-cell intensities have a tendency to decrease from the northeast to southwest, which is more or less consistent with their disappearance as they move westward or southwestward (see Fig. 1a). This result also indicates that the cells' intensities decrease toward the west and southwest.

Figure $3 \mathrm{c}$ shows that the mean and fastest moving speeds of the TUTT cells are 6.6 and $34.5 \mathrm{~m} \mathrm{~s}^{-1}$, respectively, with 
$75 \%$ of them moving at speeds of less than $10.3 \mathrm{~m} \mathrm{~s}^{-1}$; the mean speed obtained herein is faster than that of $4.1 \mathrm{~m} \mathrm{~s}^{-1}$ found by Chen and Chou (1994). There is little systematic spatial-distribution and seasonal variation of the moving speeds, that is, not very much position or temporal dependence (not shown). The life spans of the TUTT-cell events vary from 1.0 to 29.0 days, with a mean value of 4.4 days, and $75 \%$ of them have life spans of fewer than 5.8 days (Fig. 3d); the mean life span is shorter than 6.3 days, which is the value obtained by Chen and Chou (1994). The longest-lived TUTT cell event of 29 days was initiated and then dissipated at 0000 UTC 10 June and 0000 UTC 9 July 2015, respectively, traveling a zonal distance of about $2500 \mathrm{~km}$ from $22^{\circ} \mathrm{N}, 166^{\circ} \mathrm{E}$ to $22^{\circ} \mathrm{N}, 141^{\circ} \mathrm{E}$.

\section{Vertical properties}

In this section, we examine the statistical vertical properties of cold anomalies and cyclonic vorticity centers of the TUTT cells as well as their vertical profiles, including those of height anomalies and specific humidity in the core region.

\section{a. Cold core}

Figures $4 \mathrm{a}$ and $4 \mathrm{~b}$ present the box-and-whisker plots of the peak cold-cored temperature anomalies of the TUTT cells and the altitudes at which they are located. We see that the mean, minimum, and maximum temperature anomalies of the TUTT cells are $-4.5^{\circ},-12.5^{\circ}$, and $-1.4^{\circ} \mathrm{C}$, respectively, with $75 \%$ of them having values of less than $-3.5^{\circ} \mathrm{C}$ (Fig. 4a). The mean, highest, and lowest levels at which the peak cold cores are located are 250,100, and $500 \mathrm{hPa}$, respectively, with $75 \%$ of them being located above $350 \mathrm{hPa}$ (Fig. 4b). Kelley and Mock (1982) also found the peak cold core occurring at $350 \mathrm{hPa}$, as based on upper-air observations at four open-sea stations. The spatial distribution of the cold-cored anomalies, given in Fig. 4e, shows that the cold-core intensity decreases from the north to south. In other words, TUTT cells developed in the north are generally colder in the core region than those in the south. An analysis of the spatial distribution of the cold-core altitudes reveals that the levels at which the cold-cored anomalies are peaked decrease westward (not shown). This indicates that the altitudes of the TUTT cells' peak cold cores tend to be lower, likely as a result of colder-air descent and/or continued radiative cooling (Fitzpatrick et al. 1995), as they move westward to the offshore regions of East Asia.

\section{b. Vorticity center}

As one of the important characteristics of TUTT-cell intensity indicators, Fig. $4 \mathrm{c}$ shows the boxplots of the altitudes of their peak relative vorticity or vorticity centers. The mean, lowest, and highest altitudes of the vorticity centers are located at 225,500 , and $150 \mathrm{hPa}$, respectively, with $75 \%$ of them occurring above $250 \mathrm{hPa}$. The depths of positive vorticity of the TUTT cells can be estimated by determining the bottom levels, at which the relative vorticity could still remain positive. It is obvious from Fig. $4 \mathrm{~d}$ that the mean bottom level of positive vorticity occurs at $550 \mathrm{hPa}$, with $75 \%$ of the samples being above $650 \mathrm{hPa}$. In addition, we find that the mean top level of the positive vorticity appears at $125 \mathrm{hPa}$, with $97 \%$ of the samples being between 150 and $100 \mathrm{hPa}$ (not shown). So, on average, TUTT cells appear as positive relative vorticity columns confined in the 550 125 -hPa layer, which is similar to results found by previous studies (Kelley and Mock 1982; Chen and Chou 1994). A few samples' positive vorticity columns could even extend to $1000 \mathrm{hPa}$ (not shown); they may be closely related to the development of surface low pressure systems.

\section{c. Vertical profiles}

After seeing the statistical vertical locations of the peak cold core and coldness depth, it is desirable to see the vertical profiles of the mean temperature and moisture anomalies in the core region of the TUTT cells. For this purpose, Fig. 5a presents their mean vertical profiles in the core region (i.e., covering $300 \mathrm{~km} \times 300 \mathrm{~km}$ ), exhibiting negative temperature anomalies between 650 and $200 \mathrm{hPa}$, with a minimum anomaly of $-2.4^{\circ} \mathrm{C}$ at $350 \mathrm{hPa}$ (or 9-km altitude). Positive temperature anomalies appear above $200 \mathrm{hPa}$ (or 12-km altitude), which is hydrostatically consistent with a lower height depression at that level (cf. Fig. 5b). Figure 5a also shows the vertical profile of the mean specific humidity anomaly having negative values between 750 and $150 \mathrm{hPa}$ with a minimum value of $-0.4 \mathrm{~g} \mathrm{~kg}^{-1}$ at $600 \mathrm{hPa}$ (or $4.5-\mathrm{km}$ altitude). This indicates the presence of a drier column in the middle-to-upper troposphere.

The vertical profile of geopotential height anomalies is given in Fig. 5b, showing negative (positive) values above (below) $450 \mathrm{hPa}$, with minimum values of -5.6 dam at $200 \mathrm{hPa}$. The vertical profile of the mean relative vorticity, given in red in Fig. 5b, shows obvious cyclonic vorticity (i.e., greater than $10^{-5} \mathrm{~s}^{-1}$ ) above $550 \mathrm{hPa}$ in the core region of the TUTT cell, with a maximum value of $9.0 \times 10^{-5} \mathrm{~s}^{-1}$ at $200 \mathrm{hPa}$. This peak cyclonic vorticity level is geostrophically consistent with that of the peak height depression. This implies that TUTT cells are indeed upper-tropospheric circulation systems, and the 550-125-hPa layer may be used to represent the average depth of a TUTT cell in terms of positive relative vorticity.

\section{Composite TUTT cells}

Although the processes leading to cold-core formation, which is essential in the development of TUTT 

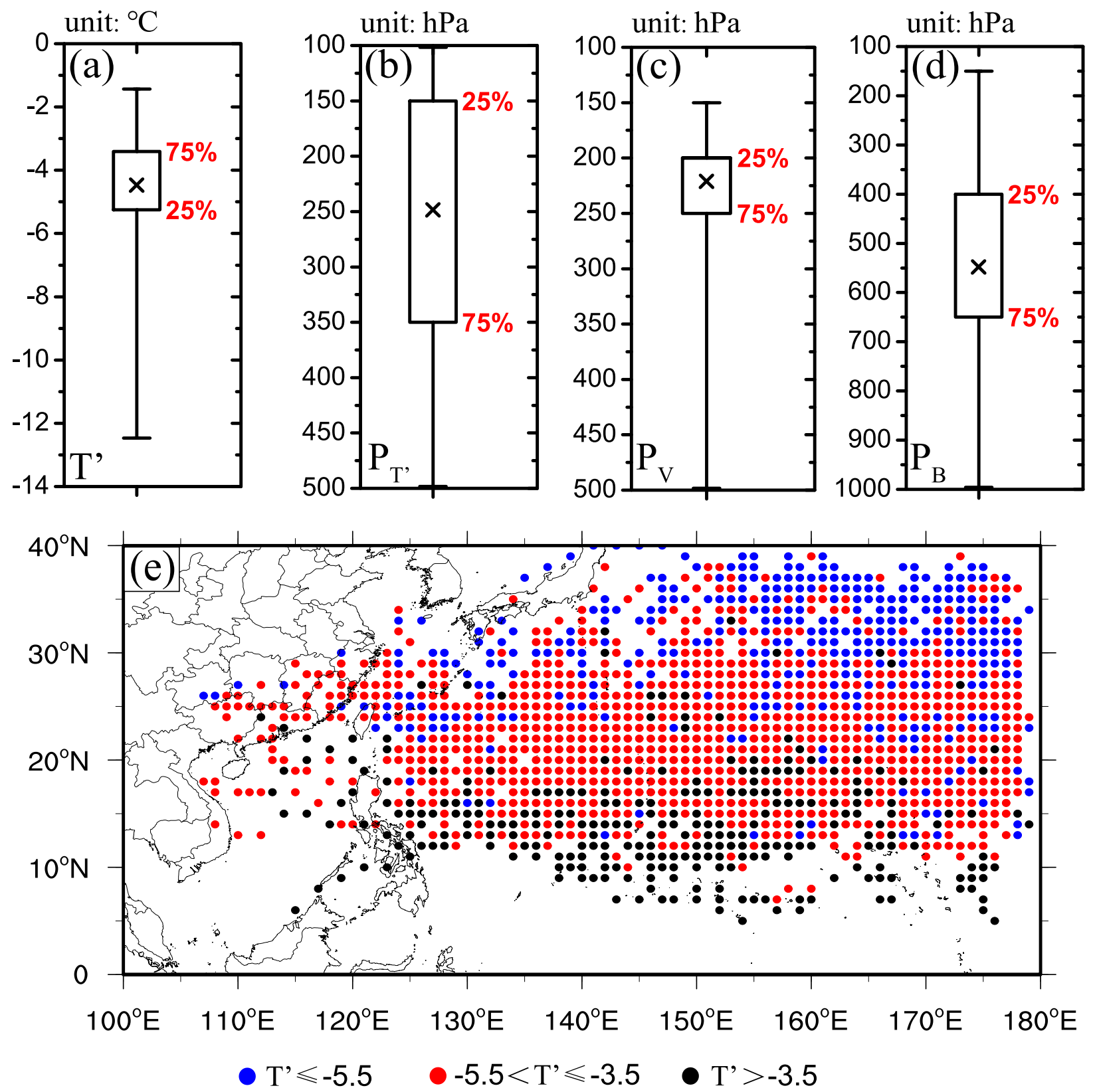

FIG. 4. As in Fig. 3, but for (a) cold-cored anomalies $T^{\prime}\left({ }^{\circ} \mathrm{C}\right)$, (b) the vertical levels of the peak cold-core intensity $P_{T^{\prime}}$ (hPa), (c) the levels at which the relative vorticity of the TUTT cells is peaked $P_{V}(\mathrm{hPa})$, and $(\mathrm{d})$ the lowest levels at which the cells' relative vorticity in vertical columns remains positive $P_{B}(\mathrm{hPa})$, and (e) the geographical distribution of the TUTT cells' peak cold-cored temperature anomaly, as determined by the minimum value in the 500-100-hPa layer (dots in blue, red, and black denote $T^{\prime} \leq-5.5^{\circ},-5.5^{\circ}<T^{\prime} \leq-3.5^{\circ}$, and $T^{\prime}>-3.5^{\circ} \mathrm{C}$, respectively).

cells, still remain elusive, some studies suggest that certain cold cores are a result of "cloud free" radiative cooling in the eastern flank of TUTTs (Fitzpatrick et al. 1995), whereas others indicate the cutoff of cold-core lows from midlatitude disturbances, as mentioned in section 1 . To help to understand the formation, structures, and evolution of TUTT cells, 20 cells each from the eastern (initial developing phase, around $170^{\circ} \mathrm{E}$ ) and central (mature phase, around $150^{\circ} \mathrm{E}$ ) open sea, and the offshore (dissipation phase, around $130^{\circ} \mathrm{E}$ ) region of the WNP are selected to form their composite structures (see Fig. 1b) and then are compared. The 20 cells used for the composites include the 13 TUTT-cell events that moved from the eastern to western WNP regions and the remaining 7 cells for each composite that are selected just on the basis of their well-defined vortex structures. 

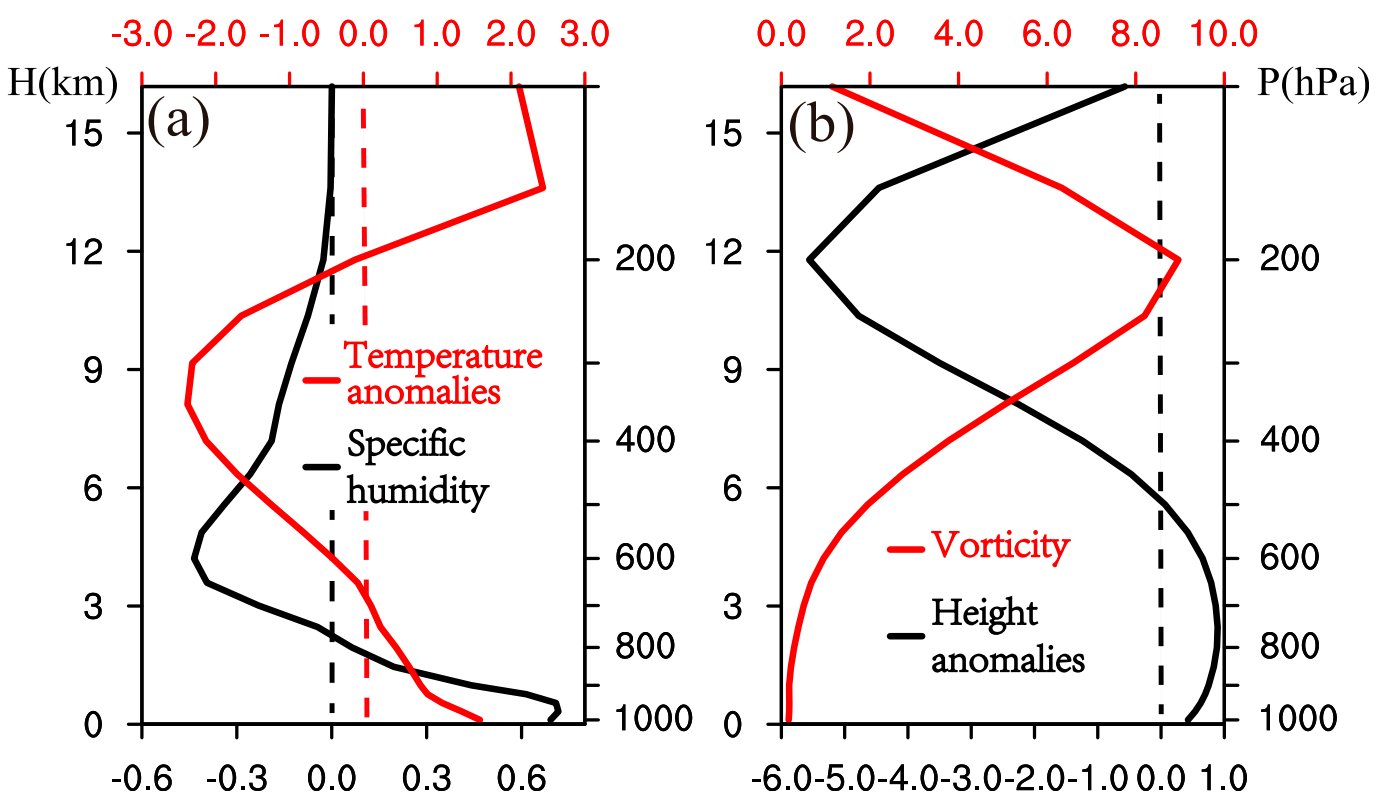

FIG. 5. The vertical profiles of (a) the mean temperature anomalies $\left({ }^{\circ} \mathrm{C}\right.$; red; top $x$ axis) and the mean specific humidity anomalies ( $\mathrm{g} \mathrm{kg}^{-1}$; black; bottom $x$ axis) and (b) the mean height anomalies (dam; black; bottom $x$ axis) and the mean vorticity $\left(10^{-5} \mathrm{~s}^{-1}\right.$; red; top $x$ axis) of the TUTT cells during the 10 -yr period of 2006-15. The left and right $y$ axes denote height $(\mathrm{km})$ and pressure $(\mathrm{hPa})$ coordinates, respectively.

The three composite TUTT cells so constructed may be considered as the representative circulations of their early formation, mature, and dissipation stages, respectively.

\section{a. TUTT-cell larger-scale circulations}

Figures $6 \mathrm{a}-\mathrm{c}$ compare the horizontal flow and geopotential heights at $200 \mathrm{hPa}$ and temperature at $300 \mathrm{hPa}$, where the height depression and cold anomalies are peaked, of the composite TUTT cells occurring over the abovementioned three different locations across the WNP. First, we see an elongated, northeast-southwestoriented climatological TUTT, stretching across more than $30^{\circ}$ latitude (much outside the maps) over a distance of more than $4000 \mathrm{~km}$ with its southwestern end situated in a subtropical high (Figs. 6a,b). Superimposed on it is a southward-penetrating midlatitude trough with a baroclinic origin. A TUTT cell is about to be formed with a closed vortex circulation at the trough base where stronger rotation is evident (Fig. 6a). The cell is characterized by a pronounced cold core originating from higher latitudes and by stronger height gradients (or rotational winds) in the northwestern quadrant. The steering flow calculated over a $10^{\circ} \times 10^{\circ}$ grid area at $200 \mathrm{hPa}$ indicates its southward movement into the TUTT, which is shifted from its eastward movement after penetrating into the northeast-southwestoriented TUTT. As the TUTT cell moves southward and later southwestward, the cell tends to separate from the midlatitude westerlies and becomes a cutoff low embedded in the TUTT.

The above scenario is indeed the case in the central WNP region where the cell is completely cut off, with a higher height to the north and a lower height to the south, which accounts geostrophically for the presence of a general westward steering flow (Fig. 6b). In addition, the cold-core intensity and thermal contrast of the cell decrease as it moves southwestward (cf. Figs. 6a and $6 b$ ). During the dissipation stage (i.e., over the offshore region), the TUTT cell is about to be encircled more, with a much weaker cold core (i.e., $4^{\circ} \mathrm{C}$ warmer) than that at the early formation stage (cf. Figs. 6a and $6 \mathrm{c}$ ). The cell is gradually dissipated in the northeasterly flow of the TUTT, as the cold-core intensity diminishes (not shown).

Figures $6 \mathrm{a}-\mathrm{c}$ also show the varying diameters of the maximum rotational winds between the TUTT cells at the three locations. That is, the offshore cell has an average diameter of about $7^{\circ}-8^{\circ}$, as indicated by the outermost closed high contour, as compared with about $10^{\circ}-11^{\circ}$ at the earlier stages, which is consistent with the diminishing intensity and circulation of TUTT cells as they move westward.

\section{b. Secondary circulation}

Figure 7 compares the vertical cross-sectional structures of secondary circulations between the composite 

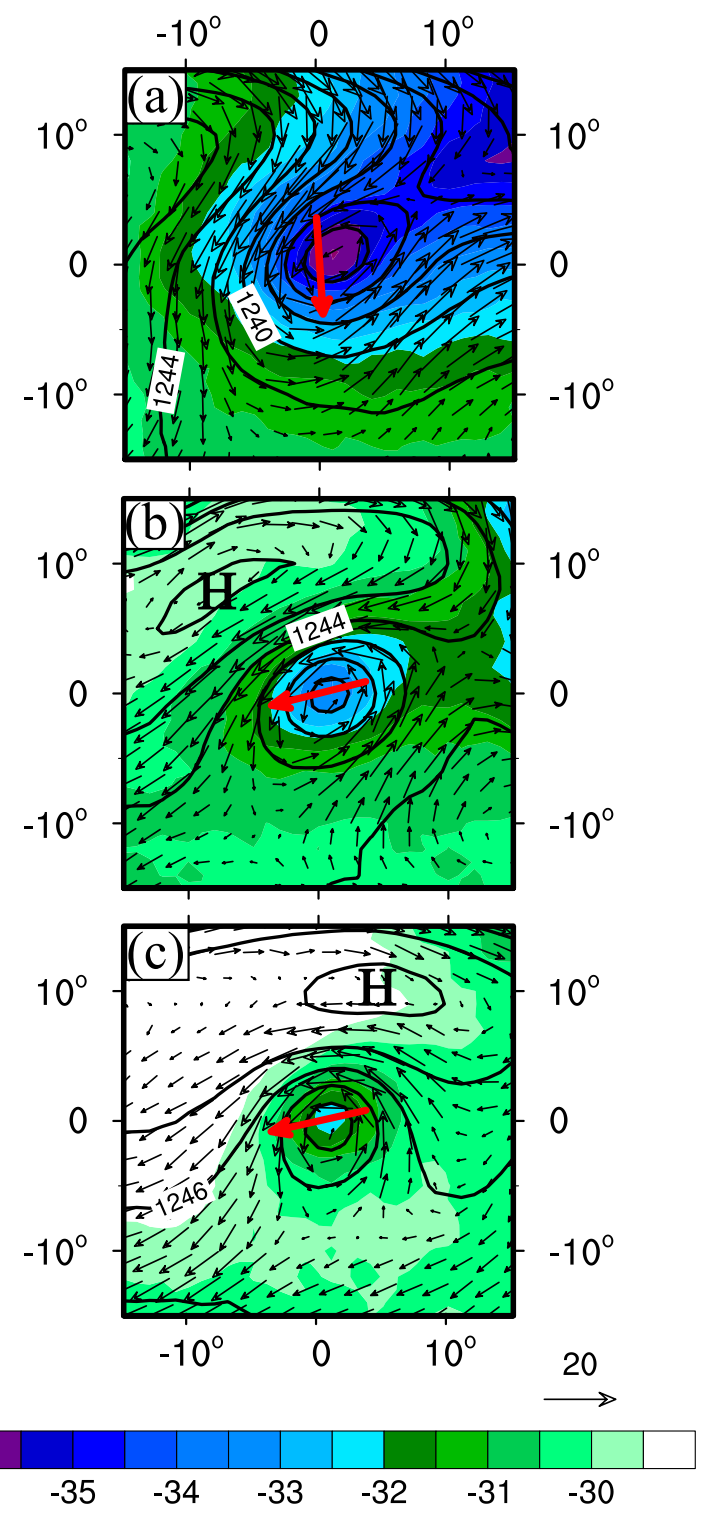

FIG. 6. Horizontal distribution of the horizontal wind vectors $\left(\mathrm{m} \mathrm{s}^{-1}\right)$, geopotential heights (contoured in black at intervals of 2 dam) at $200 \mathrm{hPa}$, and temperature (shaded) at $300 \mathrm{hPa}$ of the composite TUTT cell occurring over (a) the eastern WNP, (b) the central WNP, and (c) the offshore region, taken from the TUTT-cell samples shown by the black, red, and purple dots, respectively, in Fig. 1b. The red arrow indicates the averaged steering flow direction over a $10^{\circ} \times 10^{\circ}$ area centered at the composite cell. Horizontal and vertical axes indicate distances $\left(^{\circ}\right)$ from the composite cell center.

TUTT cells taken over the abovementioned three characteristic areas. It is evident that all of the TUTT cells are dominated more by organized descending motion below $200 \mathrm{hPa}$, especially in the northern and western portions of the eastern WNP cell (Figs. 7a,d), with relatively weak vertical motion occurring near the center. Similarly, a deep layer of upward motion appears in the southern portion of the cells (Figs. 7a-c). Such vertical circulation structures are more or less determined by thermal advection with cold (warm) air from the north (south), as can be seen from height contours intersecting with isotherms (see Figs. 6a-c). The vertical cross-sectional circulation structures of the eastern WNP cell are similar to those shown by Kelley and Mock (1982), since the TUTT cell they analyzed is close to that shown in Fig. 6a. However, the west-east vertical circulation of the TUTT cell reverses sign, after it is completely cut off from the cold-air source of the midlatitude disturbances and then moves southwestward into a warmer air mass. That is, a deep layer of significant ascending and descending motions appears in the west and east portions of the TUTT cell, which are opposite in sign to those in the eastern WNP (cf. Figs. 7d, $7 \mathrm{e}$, and $7 \mathrm{f}$ ). As the cell moves farther southwestward, the upper-level descending motion weakens significantly, which is consistent with the weakening of the coldness in the core region (cf. Figs. 6 and 7).

\section{c. Thermal and vorticity structures}

Figure 8 compares the vertical cross-sectional structures of the mean temperature deviations (shaded), vertical relative vorticity (contoured in black), and height deviations (contoured in purple) through the composite TUTT-cell centers between the three characteristic areas. The deviations are calculated with respect to individual level averages in the cross section. All the TUTT cells exhibit the peak cyclonic vorticity and height deviations near $200 \mathrm{hPa}$ (or 12-km altitude), with warm and cold deviations (with respect to the level averages in the plane) above and below, respectively. However, the intensity and lateral scale of the upperlevel warm core (more than $2.5 \mathrm{C}^{\circ}$ ) associated with the eastern WNP cell are greater than those (less than $2^{\circ} \mathrm{C}$ ) for the central and offshore cells, as can be expected from those shown in Figs. 6a-c. Despite the weakening of the upper-level warm core, the lower-level cold core experiences smaller changes in its intensity after moving to the offshore region, with similar results for the cyclonic vorticity, although it shrinks in depth and lateral size. In particular, the vertically upright cold cores remain robust from the eastern to western WNP regions. All these results are likely from the presence of weak vertical wind shear in the lower troposphere on the south of the subtropical high. Note that the thermal deviations exhibit vertically tilted structures above $300 \mathrm{hPa}$, which is a typical feature of baroclinicity, since this is a cutoff low from midlatitude disturbances. Nevertheless, the vertical tilts become less evident with time, especially to the north after the cells are completely cut off from the midlatitude influences (Figs. 8a-c). 


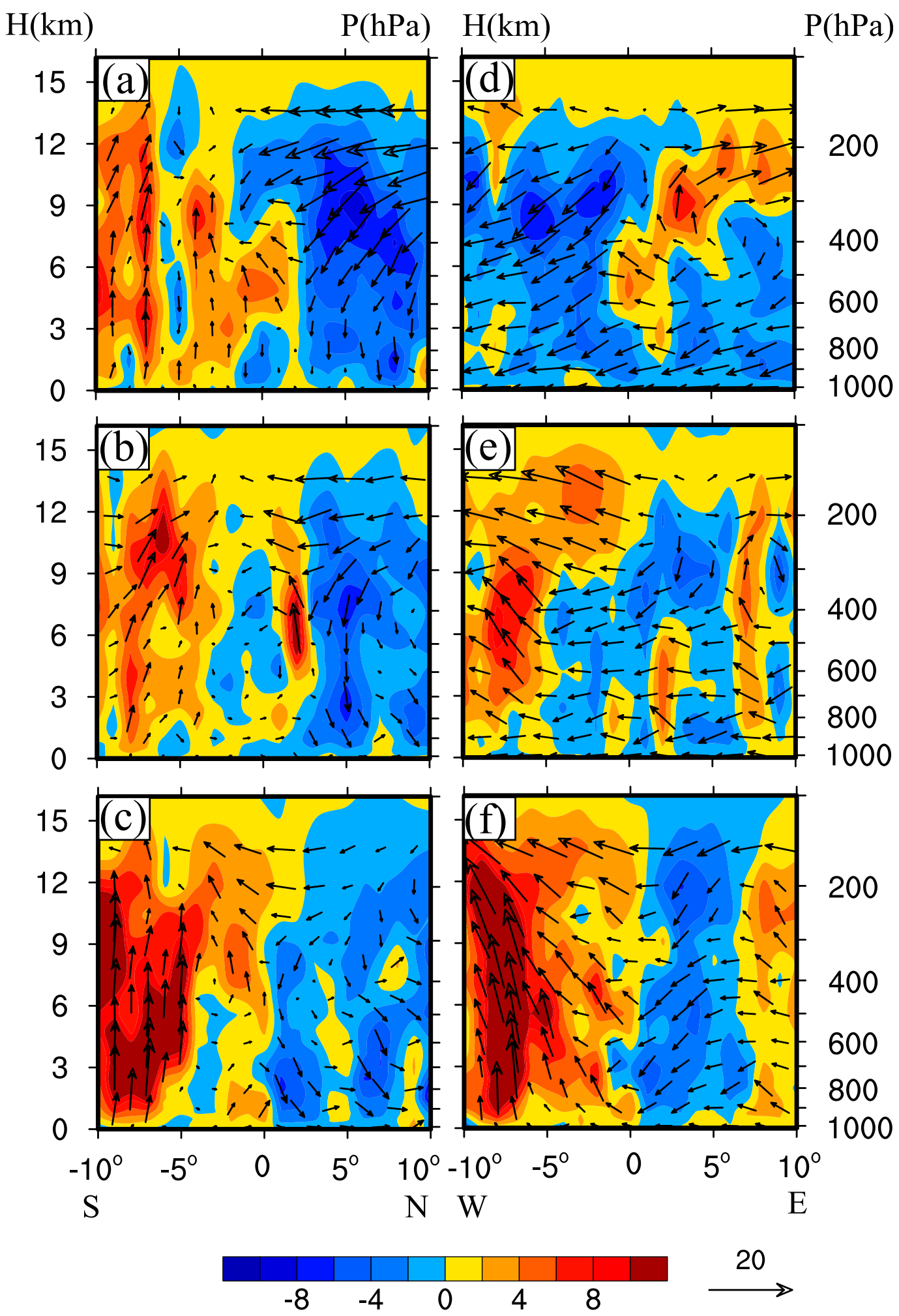

FIG. 7. Vertical cross sections of the vertical motion (shaded; $10^{-1} \mathrm{~cm} \mathrm{~s}^{-1}$ ), superimposed with (left) meridional (i.e., south-north) in-plane flow vectors (i.e., $v$ and $-100 \times w)$ and (right) zonal (i.e., west-east) in-plane flow vectors (i.e., $u$ and $-100 \times w$ ) through the centers of the composite cells occurring over (a),(d) the eastern WNP, (b),(e) the central WNP, and (c),(f) the offshore region. Letters E, S, W, and N denote the east, south, west, and north directions, respectively. 


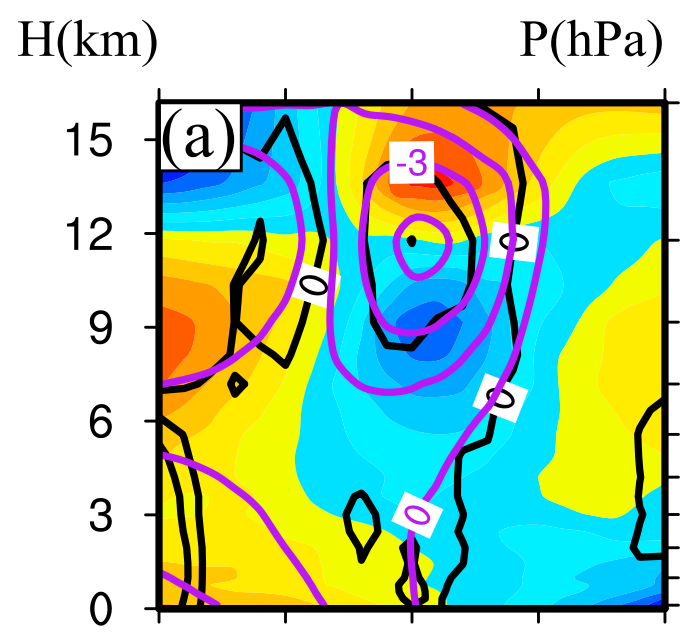

$\mathrm{H}(\mathrm{km})$

$\mathrm{P}(\mathrm{hPa})$
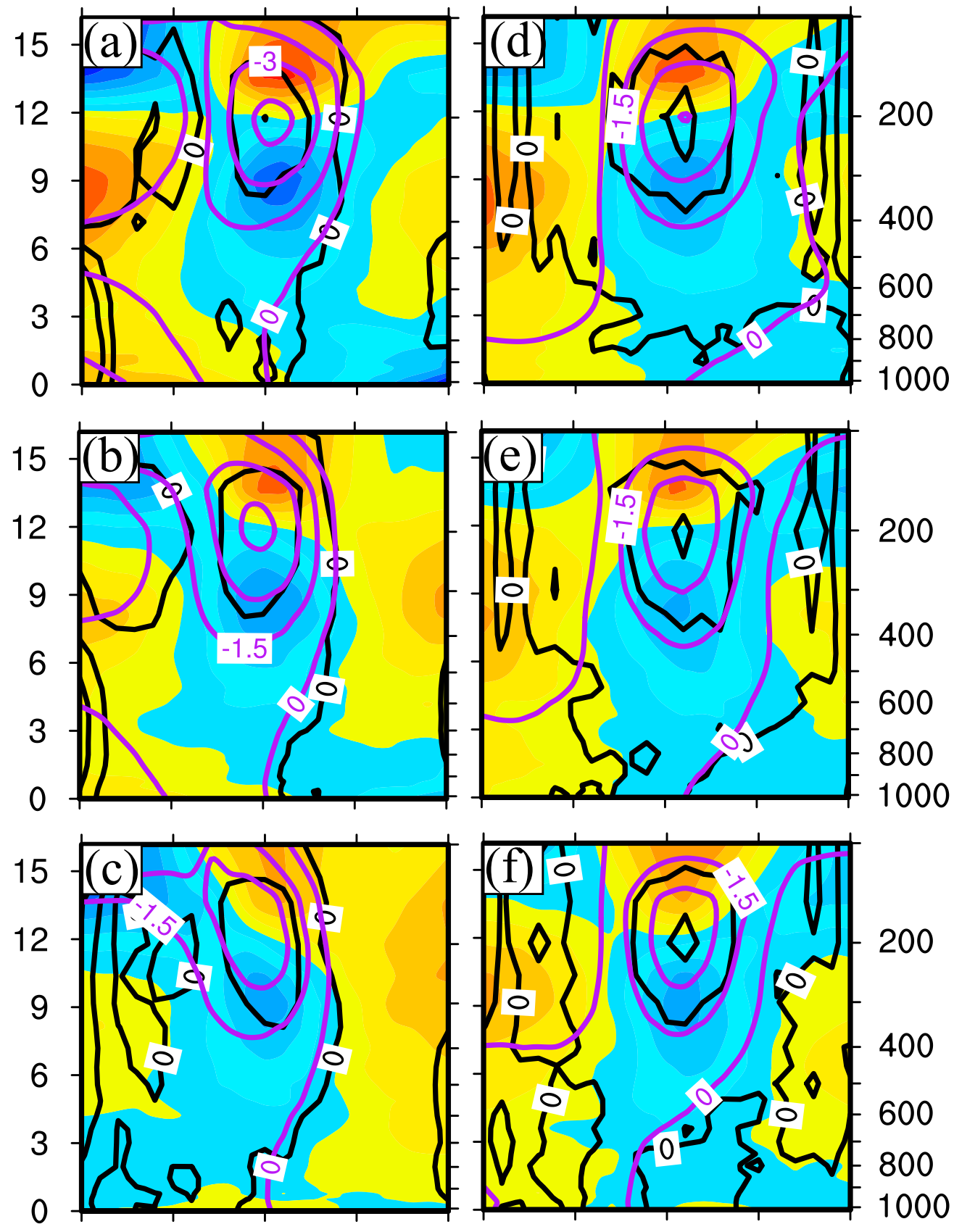

12

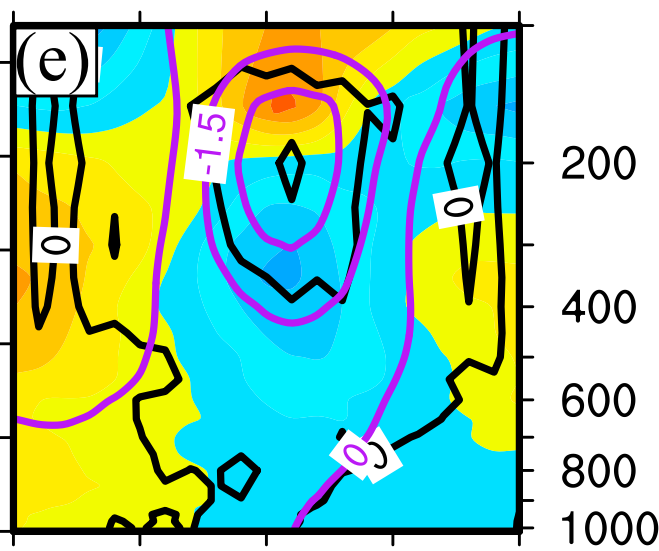

$\begin{array}{ccccccccc}-10^{\circ} & -5^{\circ} & 0 & 5^{\circ} & 10^{\circ}-10^{\circ} & -5^{\circ} & 0 & 5^{\circ} & 10^{\circ} \\ \mathrm{S} & & & & \mathrm{N} & \mathrm{W} & & & \\ \mathrm{E}\end{array}$

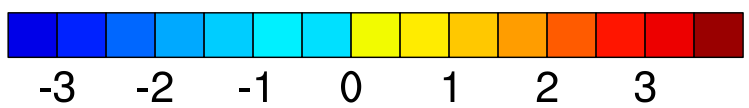

FIG. 8. As in Fig. 7, but for temperature deviations (shaded; ${ }^{\circ} \mathrm{C}$ ), vertical cyclonic relative vorticity (contoured in black at intervals of $0.5 \times 10^{-5} \mathrm{~s}^{-1}$ ), and height deviations (contoured in purple at intervals of 1.5 dam only for negative values) of the composite TUTT cells. A deviation is calculated with respect to a level average in the cross section. 
It is important to mention that although the TUTT cells are upper-level disturbances in nature, their influences may extend to the lower troposphere, even to the surface through cold deviations and height/pressure depressions, albeit much smaller in magnitude than those aloft. This implies that the passage of a TUTT cell could indeed help induce tropical cyclogenesis under certain favorable environmental conditions, or influence the movement and development of nearby TCs (Sadler 1976; DeMaria et al. 1993; Patla et al. 2009; Li et al. 2012).

Figure 9 shows the net temperature and height changes in the vertical planes through the TUTT cells during their movement from the eastern to western WNP regions (Figs. 9a,b). In general, the troposphere (lower stratosphere) experiences warming (cooling) as the cells move southwestward into warmer air with a higher tropopause. Clearly, the upper vortex layers exhibit the most significant warming below cooling, as a result of the weakening of the cold cores. The maximum warming near $300 \mathrm{hPa}$ in the northern semicircle is as large as $4^{\circ} \mathrm{C}$. As a result, the lower troposphere experiences height falls, but height deviations increase aloft with the greatest amount in the upper-core layers after moving to the offshore region, especially in the northern semicircle.

As a final note, one may wonder if the above results are sensitive to different analysis data, given the limited horizontal and vertical resolutions and uncertainties over the vast oceans where most data are from satellite observations. To address the above issue, we have reconstructed the composite TUTT cells during the different phases, as shown in Figs. 6-9, using the European Centre for Medium-Range Weather Forecasts $0.75^{\circ} \times$ $0.75^{\circ}$ resolution reanalysis data. We find very minor differences in the statistical characteristics of the TUTT cells from the two different datasets (not shown).

\section{Summary and concluding remarks}

Motivated by a growing interest in the roles of upperlevel disturbances in TC development, we identify a total of 369 TUTT-cell events or 6836 TUTT cells, when viewed at 6-hourly intervals, over the WNP from the NCEP FNL reanalysis during the period of 2006-15. It is found that most TUTT cells move westward or southwestward with a mean speed of $6.6 \mathrm{~m} \mathrm{~s}^{-1}$ and have a mean life span of 4.4 days, and we find that 13 of them could travel a long distance from the eastern to western portions of the WNP with well-defined vortex structures. Moreover, most TUTT cells occur during the active months (i.e., May-October) of typhoon development and over an elongated open-sea zone of $15^{\circ}-25^{\circ} \mathrm{N}$ and
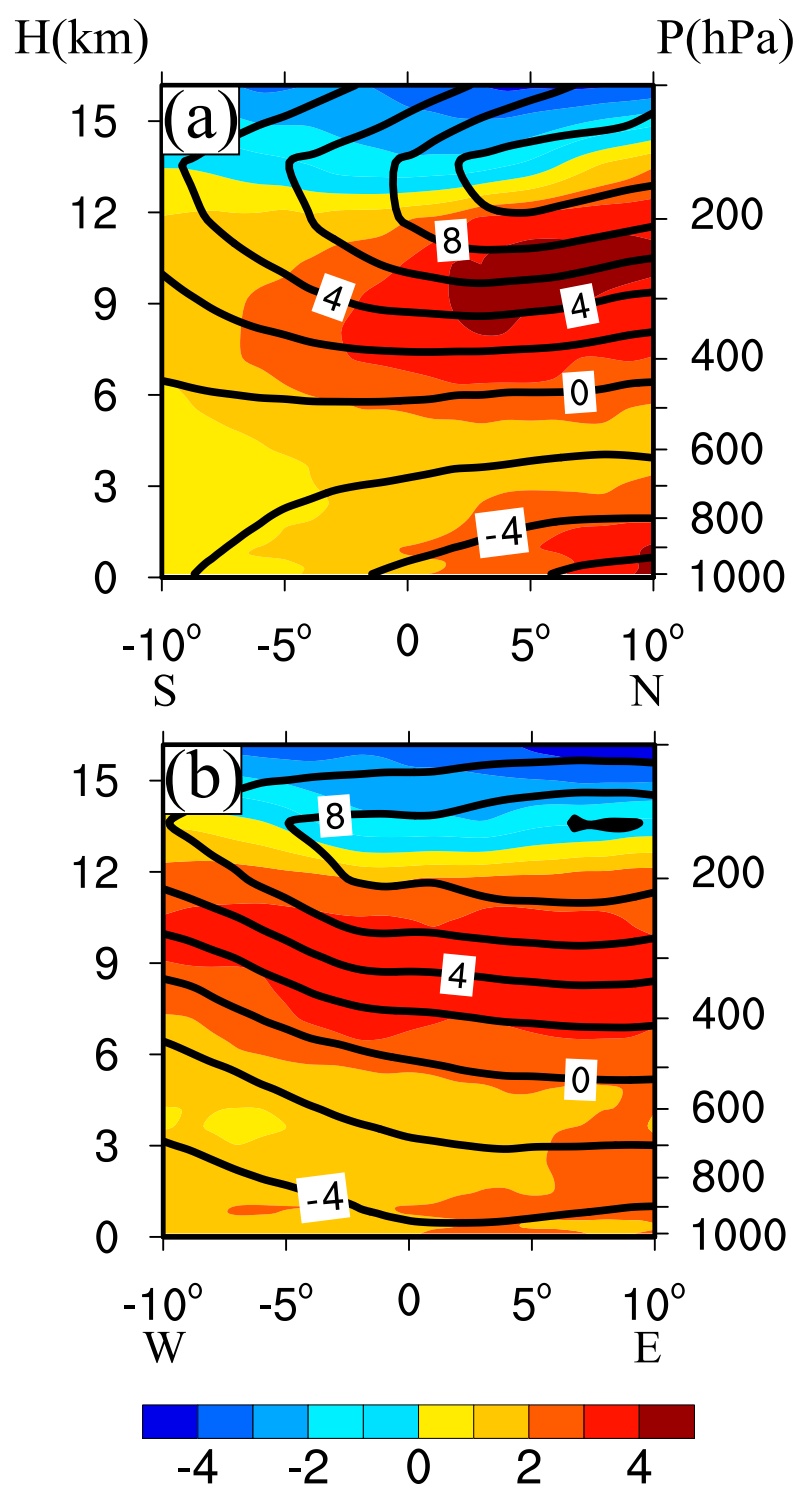

FIG. 9. Vertical cross sections of the net height (contoured in black at intervals of 2 dam) and temperature (shaded; ${ }^{\circ} \mathrm{C}$ ) changes (a) meridionally and (b) zonally through the offshore TUTT cell center with respect to that in the eastern WNP. Letters E, S, W, and $\mathrm{N}$ denote the east, south, west, and north directions, respectively.

$150^{\circ}-175^{\circ} \mathrm{E}$. A statistical analysis of the TUTT-cell events shows that about $75 \%$ of them exhibit radii of $<500 \mathrm{~km}$ with negative height anomalies above $450 \mathrm{hPa}$, cold anomalies in the 650-200-hPa layer, and significant cyclonic vorticity above $550 \mathrm{hPa}$.

Three composite TUTT cells over the eastern and central open sea and the offshore region of the WNP, respectively, are analyzed to investigate their different vortex-scale structures, intensities, and larger-scale circulations. Results show the southward penetration of a midlatitude trough with a baroclinic origin into an 
elongated, northeast-southwest-oriented climatological TUTT during the early formation stage of the TUTT cells. A cold-cored TUTT cell is formed with a closed vortex circulation at the trough base. The TUTT cell initially moves southward during its penetration into the climatological TUTT, and then southwestward under the influence of the TUTT's northeasterly flow, after being cut off from the midlatitude disturbances. The TUTT cell weakens in rotation and shrinks in size, gradually dissipated after arriving at the western WNP region.

A vertical cross-sectional analysis of the composite TUTT cells shows vertically tilted (i.e., baroclinic) structures above $300 \mathrm{hPa}$ with more pronounced descending (ascending) motion in the north and west (south and east) in the upper troposphere during the early formation stage. The above structures become less baroclinic as the cell moves southwestward, and the zonal secondary circulation associated with the offshore cell reverses in sign from that in the eastern WNP cell, that is, with pronounced ascent and descent in the west and east semicircles, respectively. While the TUTT cells weaken westward, the lower-level cold core and cyclonic vorticity experience smaller changes in their intensities even after moving to the offshore region.

In conclusion, although the TUTT cells are west-tosouthwestward-propagating upper-level disturbances in nature, their influences could extend to the surface through cold deviations and height/pressure depressions, likely influencing tropical cyclogenesis and the movement and development of TCs. Of course, some selected case studies should be performed to examine the mesoscale processes (e.g., the cutting off of cold-core lows) involved in the early formation stage of the TUTT cells, the maintenance and downward penetration of the upper-level cold core and cyclonic vorticity (e.g., radiative cooling and colder-air descent) during their tropical transition, as well as their impact on the development of TCs.

Acknowledgments. This work was funded by the National Basic Research Program of China (973 Programs: 2015CB452804 and 2014CB441402); National Natural Science Foundation of China Grants 41475055, 41475061, and 41275093; and the U.S. Office of Naval Research Grants N000141410143 and N000141712210.

\section{REFERENCES}

Abatzoglou, J. T., 2016: Contribution of cutoff lows to precipitation across the United States. J. Appl. Meteor. Climatol., 55, 893899, https://doi.org/10.1175/JAMC-D-15-0255.1.

Campetella, C. M., and N. E. Possia, 2007: Upper-level cut-off lows in southern South America. Meteor. Atmos. Phys., 96, 181191, https://doi.org/10.1007/s00703-006-0227-2.
Chen, G. T.-J., and L.-F. Chou, 1994: An investigation of cold vortices in the upper troposphere over the western North Pacific during the warm season. Mon. Wea. Rev., 122, 14361448, https://doi.org/10.1175/1520-0493(1994)122<1436: AIOCVI $>2.0 . \mathrm{CO} ; 2$.

Chen, T. C., M.-C. Yen, G.-R. Liu, and S.-Y. Wang, 2001: Summer upper-level vortex over the North Pacific. Bull. Amer. Meteor. Soc., 82, 1991-2006, https://doi.org/10.1175/ 1520-0477-82.9.1991.

Chiodi, A. M., and D. E. Harrison, 2017: Observed El Niño SSTA development and the effects of easterly and westerly wind events in 2014/15. J. Climate, 30, 1505-1519, https://doi.org/ 10.1175/JCLI-D-16-0385.1.

Cochran, D. R., 1976: Unusual tropical development from a midPacific cold low. Mon. Wea. Rev., 104, 804-808, https://doi.org/ 10.1175/1520-0493(1976)104<0804:UTDFAM>2.0.CO;2.

Colton, D. E., 1973: Barotropic scale interactions in the tropical upper troposphere during the northern summer. J. Atmos. Sci., 30, 1287-1302, https://doi.org/10.1175/1520-0469(1973) $030<1287$ :BSIITT $>2.0$.CO;2.

DeMaria, M., J. Kaplan, and J. Baik, 1993: Upper-level eddy angular momentum flux and tropical cyclone intensity change. J. Atmos. Sci., 50, 1133-1147, https://doi.org/10.1175/15200469(1993)050<1133:ULEAMF>2.0.CO;2.

Ferreira, R. N., and W. H. Schubert, 1999: The role of tropical cyclones in the formation of tropical upper-tropospheric troughs. J. Atmos. Sci., 56, 2891-2907, https://doi.org/10.1175/1520-0469 (1999)056<2891:TROTCI >2.0.CO;2.

Fitzpatrick, P. J., J. A. Knaff, C. W. Landsea, and S. V. Finley, 1995: Documentation of a systematic bias in the Aviation Model's forecast of the Atlantic tropical upper-tropospheric trough: Implications for tropical cyclone forecasting. Wea. Forecasting, 10, 433-446, https://doi.org/10.1175/1520-0434(1995) $010<0433$ :DOASBI $>2.0$.CO;2.

Gray, W. M., 1968: Global view of the origin of tropical disturbances and storms. Mon. Wea. Rev., 96, 669-700, https://doi.org/10.1175/ 1520-0493(1968)096<0669:GVOTOO>2.0.CO;2.

Hirota, N., Y. N. Takayabu, M. Kato, and S. Arakane, 2016: Roles of an atmospheric river and a cutoff low in the extreme precipitation event in Hiroshima on 19 August 2014. Mon. Wea. Rev., 144, 1145-1160, https://doi.org/10.1175/ MWR-D-15-0299.1.

Kelley, W. E., Jr., and D. R. Mock, 1982: A diagnostic study of upper tropospheric cold lows over the western North Pacific. Mon. Wea. Rev., 110, 471-480, https://doi.org/10.1175/15200493(1982)110<0471:ADSOUT>2.0.CO;2.

Kim, W., S.-W. Yeh, J.-H. Kim, and J.-S. Kug, 2011: The unique 2009-2010 El Niño event: A fast phase transition of warm pool El Niño to La Niña. Geophys. Res. Lett., 38, L15809, https:// doi.org/10.1029/2011GL048521.

Kousky, V. E., and M. A. Gan, 1981: Upper tropospheric vortices in the tropical South Atlantic. Tellus, 33, 538-551, https:// doi.org/10.3402/tellusa.v33i6.10775.

Li, Y., L. Guo, Y. Ying, and S. Hu, 2012: Impacts of upper-level cold vortex on the rapid change of intensity and motion of Typhoon Meranti (2010). J. Trop. Meteor., 18, 207-219.

Nieto, R., and Coauthors, 2005: Climatological features of cutoff low systems in the Northern Hemisphere. J. Climate, 18, 30853103, https://doi.org/10.1175/JCLI3386.1.

Palmén, E., and K. M. Nagler, 1949: The formation and structure of a large-scale disturbance in the westerlies. J. Atmos. Sci., 6, 227-242, https://doi.org/10.1175/1520-0469(1949) $006<0228$ :TFASOA $>2.0 . \mathrm{CO} ; 2$. 
Palmer, C. E., 1953: The impulsive generation of certain changes in the tropospheric circulation. J. Atmos. Sci., 10, 1-9, https://doi.org/ 10.1175/1520-0469(1953)010<0001:TIGOCC $>2.0 . C O ; 2$.

Patla, J. E., D. Stevens, and G. M. Barnes, 2009: A conceptual model for the influence of TUTT cells on tropical cyclone motion in the northwest Pacific Ocean. Wea. Forecasting, 24, 1215-1235, https://doi.org/10.1175/2009WAF2222181.1.

Pinheiro, H. R., K. I. Hodges, M. A. Gan, and N. J. Ferreira, 2017: A new perspective of the climatological features of upperlevel cut-off lows in the Southern Hemisphere. Climate Dyn., 48, 541-559, https://doi.org/10.1007/s00382-016-3093-8.

Sadler, J. C., 1975: The monsoon circulation and cloudiness over the GATE area. Mon. Wea. Rev., 103,369-387, https://doi.org/ 10.1175/1520-0493(1975)103<0369:TMCACO >2.0.CO;2.

_ 1976: A role of the tropical upper tropospheric trough in early season typhoon development. Mon. Wea. Rev., 104, 12661278, https://doi.org/10.1175/1520-0493(1976)104<1266: AROTTU $>2.0 . \mathrm{CO} ; 2$.

_ 1978: Mid-season typhoon development and intensity changes and the tropical upper tropospheric trough. Mon. Wea. Rev., 106, 1137-1152, https://doi.org/10.1175/1520-0493(1978)106<1137: MSTDAI $>2.0 . \mathrm{CO} ; 2$.

Singleton, A. T., and C. J. C. Reason, 2007: A numerical model study of an intense cutoff low pressure system over South Africa. Mon Wea. Rev., 135, 1128-1150, https://doi.org/10.1175/MWR3311.1.
Thorncroft, C. D., B. J. Hoskins, and M. E. Mclntyre, 1993: Two paradigms of baroclinic-wave life-cycle behavior. Quart. J. Roy. Meteor. Soc., 119, 17-55, https://doi.org/ 10.1002/qj.49711950903.

Wang, C., and L. Wu, 2016: Interannual shift of the tropical upper-tropospheric trough and its influence on tropical cyclone formation over the western North Pacific. J. Climate, 29, 4203-4211, https://doi.org/10.1175/JCLI-D-15-0653.1.

Wang, M. Y.-M., G. T.-J. Chen, C.-C. Wang, and Y.-H. Kuo, 2012: A case study of the cutoff process and latent heating effect in an upper-level cold-core low during the mei-yu season in East Asia. Mon. Wea. Rev., 140, 1725-1747, https://doi.org/10.1175/ MWR-D-11-00306.1.

Wei, N., Y. Li, D.-L. Zhang, Z. Mai, and S.-Q. Yang, 2016: A statistical analysis of the relationship between upper-tropospheric cold low and tropical cyclone track and intensity change over the western North Pacific. Mon. Wea. Rev., 144, 1805-1822, https://doi.org/10.1175/MWR-D-15-0370.1.

Whitfield, M. B., and S. W. Lyons, 1992: An upper-tropospheric low over Texas during summer. Wea. Forecasting, 7, 89-106, https://doi.org/10.1175/1520-0434(1992)007<0089: AUTLOT>2.0.CO;2.

Wu, G. X., 1992: Tropical storm formation in response to sea surface temperature anomaly (in Chinese). J. Atmos. Sci., 16, $322-332$. 